\title{
Can Top Management Teams' Academic Experience Promote Green Innovation Output: Evidence from Chinese Enterprises
}

\author{
Shukuan Zhao ${ }^{1}$, Bochen Zhang ${ }^{1, *}$, Dong Shao ${ }^{2}$ and Shuang Wang ${ }^{1}$ \\ 1 School of Management, Jilin University, Changchun 130022, China; zhaosk@jlu.edu.cn (S.Z.); \\ wanglong16@mails.jlu.edu.cn (S.W.) \\ 2 Business School, Northeast Normal University, Changchun 130117, China; shaodong16@mails.jlu.edu.cn \\ * Correspondence: zhangbc20@mails.jlu.edu.cn
}

Citation: Zhao, S.; Zhang, B.; Shao, D.; Wang, S. Can Top Management Teams' Academic Experience Promote Green Innovation Output: Evidence from Chinese Enterprises. Sustainability 2021, 13, 11453. https:// doi.org/10.3390/su132011453

Academic Editor: Luigi Aldieri

Received: 2 September 2021

Accepted: 8 October 2021

Published: 16 October 2021

Publisher's Note: MDPI stays neutral with regard to jurisdictional claims in published maps and institutional affiliations.

Copyright: (c) 2021 by the authors. Licensee MDPI, Basel, Switzerland. This article is an open access article distributed under the terms and conditions of the Creative Commons Attribution (CC BY) license (https:// creativecommons.org/licenses/by/ $4.0 /)$.
Abstract: Under the background of increasingly severe environmental problems, green innovation has become a key way to realize coordinated development of economy and environment. Therefore, it is of great significance to explore the antecedent factors of green innovation. Based on the upper-echelon theory, this study explores the influence of the academic background of top management teams (TMT) on firm's green innovation outcomes and firm performance in Chinese listed companies. This study also discusses three boundary conditions for TMT's academic experience to promote firm's green innovation. The results show that TMT's academic experience promotes green innovation output. Moreover, TMT's academic experience do not have a uniform effect: strict environmental regulation strengthens the relationship between TMT's academic experience and green innovation output, while political connection and innovation input negatively moderate this relationship. Furthermore, green innovation output does not result in better economic benefits for enterprises with top executives who have academic experience, and this condition is observed more in state-owned enterprises. This study reveals the motivation of green innovation and provides a useful reference for enterprises to implement green innovation strategy more effectively.

Keywords: academic experience; top management teams; green innovation output

\section{Introduction}

Increasing global warming and environmental degradation have led to serious concerns about sustainability [1]. Innovation, particularly green innovation, is considered essential for change and to overcome this challenge [2]. Green innovation refers to new technologies, processes, or products produced that help reduce environmental pollution and achieve sustainable development [3]. It not only makes enterprises comply with environmental regulations [4], but also creates a win-win situation [5]. Therefore, enterprises should adopt green innovation to realize coordinated development of environment and economy [6].

Given the prominent role of green innovation, its implementation has been increasingly discussed. Several studies have discussed various antecedent factors of green innovation, such as policies [7], institution [8], and public pressure [9]. Most of these studies are based on corporate external factors, while not many have explored corporate internal factors [2]. According to the upper-echelon theory, a firm's strategic planning and resource allocations depend mainly on the discretion of the top management team, which is influenced by their work experience $[10,11]$. Consistent with this view, recent research in China reveals a unique "scholars in business" economic phenomenon since the reform and opening up. People with academic experience are being employed in large numbers by listed companies [12]. Such people have better insights on the effective use of resources to undertake R\&D activities [13]. Moreover, they also have high standards of professional ethics and social responsibility, therefore, they regard green innovation as an opportunity 
rather than a threat [10]. Hence, academic experience has a significant impact on top executives' logical thinking and strategic choice [12]. However, so far, studies on the academic experience of TMT are still insufficient, and few works have explored the relationship between executives' academic experience and green innovation output.

In addition, the impact of academic experience on enterprises' green innovation output may be affected by boundary conditions. In order to cope with the increasingly severe environmental pollution, in recent years, the Chinese government has issued many laws and regulations to restrict the environmental behavior of enterprises [14], which may force enterprises to green innovation. In addition, in China, due to the imperfect institution of the market economy, the Chinese government still controls a large number of resources for enterprise activities [15]. Therefore, political connection has become an important way for enterprises to obtain resources [16], so it will have an important impact on corporate green innovation. Moreover, innovation input is also one of the important factors affecting corporate green innovation output [17]. However, the existing research has not yet explored the role of environmental regulation, political connection and innovation input between TMT's academic experience and green innovation output.

Accordingly, this study focuses on Chinese listed companies, discusses the impact of TMT's academic experience on green innovation output, and analyzes the influence of boundary conditions on the significant role of TMT's academic experience. The study also verifies whether green innovation output by enterprises with top executives who have academic experience produces better economic benefits. The study found that top managers with academic experience effectively promote enterprises' green innovation achievements, and this positive effect is more significant under strong environmental regulation. However, political connection and innovation input play a negative regulatory role in this relationship. The study also finds that green innovation inhibits the promotion effect of TMT's academic experience on firm performance, and this negative effect is more significant in state-owned enterprises (SOEs).

This study makes several important contributions. First, this study discusses the impact of TMT's unique functional background on corporate high-risk strategic decisionmaking, which enriches the literature of the upper-echelon theory. Second, this study discusses the internal governance factors of corporate green innovation, which enriches the literature on the antecedent factors that influence enterprises to undertake green innovation activities and adds a fresh perspective to literature. Third, based on the TMT perspective, this study discusses whether green innovation output can lead to better economic benefits by enterprises with top executives who have academic experience, which provides empirical evidence for the existing research.

\section{Theoretical Foundations and Hypothesis Development}

\subsection{Top Management Teams' Academic Experience and Corporate Green Innovation Output}

As part of corporate social responsibility strategy, green innovation reflects the enterprises' long-term strategic direction [18]. Hence, green innovation is considered an effective approach to reduce energy consumption and achieve coordinated development of economy and environment [19]. However, green innovation is more challenging than general innovation because it has higher complexity, greater risk, and a longer time for return on investment $[20,21]$. As important decision-makers, top executives determine corporate strategy and resource allocation [22]. Therefore, implementing green innovation strategy depends on their personal preference and judgment [23]. To date, previous studies have discussed the impact of executives' gender [24], hubris [23], hometown identity [25] and other individual characteristics on corporate green innovation, however, to our best knowledge, top executives' academic background has not received much attention. As an important and unique experience of executives, academic experience has an important impact on their personal thinking and decision-making. Therefore, this paper extends the existing literature to explore the impact of top executives' academic experience on corporate green innovation. 
According to the upper-echelon theory, professional background or experience can help top executives to shape their values and cognitive models [11], which are important for their attitude toward innovative activities [26]. Studies have shown that academic experience shapes top executives' creative thinking patterns for "discovering new things and exploring new things" $[12,27]$. Thus, new opportunities and technologies are better understood [28]. Some studies also found that top managers' educational background or R\&D experience helped in quickly adopting new ideas [27], and creating rigorous, scientific solution to the problem [29], which, in turn, helps enterprises to undertake exploratory innovation activities [13]. Moreover, top executives with academic experience often focus on the important role of resources in innovation, especially human resource [30]. Therefore, to develop innovation teams and stimulate enterprises' innovation vitality, they often choose and reward employees who have innovative intention or align with them [31].

Some studies have shown that top executives with R\&D experience are more sensitive to potential opportunities when faced with resource shortage and fierce competition [32]. Adversities bring greater awareness of the importance of exploring new technologies, therefore, such executives are more willing to improve firms' competitiveness through exploratory innovation rather than through low-risk strategy [13,33]. Moreover, because higher education itself is a tradeoff between short-term benefits and potential unknown benefits, such managers are more willing to accumulate experience in failure and accept long-term benefits [34]. Therefore, in the process, top executives gradually cultivate a spirit of persistent exploration, which helps reduce their sensitivity toward high-risk innovation activities $[35,36]$. Meanwhile, a strong psychological quality is built, which improves their tolerance of innovation failure [37]. Furthermore, "scholars" inherit the intellectuals' "feelings of nation and country", they often have high standards of professional ethics and social responsibility [38], therefore, they can better understand and assume the responsibility and obligation of environmental protection, so as to actively promote the green innovation of enterprises [39]. Based on these analyses, the following hypothesis is proposed:

Hypothesis 1 (H1). TMT's academic experience improves corporate green innovation output.

\subsection{Environmental Regulation and Green Innovation Output}

With increasing problem of environmental pollution, the government focuses on the important role of environmental supervision in the transition economy [40]. Environmental regulations demonstrate government's concerns for the environment and aim to restrain corporate illegal behaviors [14,41]. Under these circumstances, enterprises adopt environmental protection technologies or measures to reduce environmental pollution to comply with the stipulated standards $[42,43]$. Therefore, it is necessary for government to participate in corporate environmental management [44]. Some studies highlight that the fundamental driving force for enterprises to explore and develop new technologies is environmental regulation [45]. Environmental regulation can shape TMT's attitude, guide their attention, and improve their environmental awareness [46]. Therefore, TMT will actively participate in green innovation activities to reduce potential environmental costs [47]. Some studies have also found that strict environmental regulation compels enterprises to adopt environmental protection technologies or measures [47], such as green innovation [18,44], to reduce firms' illegal behavior [48]. When corporate executives find that environmental costs can be saved and long-term benefits achieved by reducing environmental pollution or adopting positive environmental strategies [49], they are more willing to win the leading edge for enterprises by engaging in environmental protection activities [18], which provides a guarantee for enterprises to implement green innovation [50]. Based on these analyses, the following hypothesis is proposed:

Hypothesis 2 (H2). The relationship between TMT's academic experience and green innovation output is strengthened for firms under strict environmental regulation. 
2.3. Moderating Role of Political Connection in the Correlation between Top Management Teams' Academic Experience and Green Innovation Output

Political connection refers to the close relationship between enterprises and governments, which is common in developed countries and emerging economies [51]. In the transitional stage, due to the imperfect institution of the market economy, the Chinese government still controls a large number of resources for corporate activities [15]. As an informal system within an enterprise, political connection can help enterprises solve market failure, therefore, enterprises have a strong incentive to establish political ties [52,53]. Previous studies have found that political connection can help enterprises acquire numerous tangible and intangible resources [16], so it has an important impact on firm performance [54] and corporate bailouts [55]. In addition, scholars have also done a lot of research on whether political connection can promote corporate green innovation.

Some studies have revealed a positive relationship between political connection and corporate green innovation achievements [56]. On the one hand, enterprises can obtain additional green subsidies and financial support through political ties [16], which relieving the financial constraints of green innovation investment [57]. On the other hand, by establishing a friendly relationship with the government, political-affiliated enterprises obtain more policy information about innovation, which favors enterprises' green innovation activities [58].

However, recent studies have shown that political connection has the resource curse effect [59], which impedes corporate green innovation [60]. For instance, to maintain the relationship with the government, affiliated enterprises often should pay more rent-seeking costs, which competes with the companies' innovation input [61]. In addition, when enterprises are politically connected, the umbrella role of the government may make affiliated enterprises evade environmental responsibility [62], which weakens the motivation and enthusiasm of top executives to improve enterprises' innovation performance [59]. Some studies have highlighted that, in China, local government officials consider the economic achievements as an important evaluation index for political promotion during their tenure, so this incentive structure encourages the government's intervention in affiliated enterprises' decision-making [58]. Consequently, affiliated enterprises are compelled to prioritize economic growth rather than environmental protection and governance [63]. Limited by political burden and other factors, affiliated enterprises often make investments at the cost of pursuing short-term economic benefits [59]. This leads to dispersal of the limited resources of enterprises and rigidity in TMT's decision-making in the development of enterprises [64]. Based on these discussions, the following hypothesis is proposed:

Hypothesis 3 (H3). Political connection weakens the relationship between TMT's academic experience and corporate green innovation output.

\subsection{The Moderating Role of Innovation Input in the Correlation between Top Management Teams' Academic Experience and Green Innovation Output}

Innovation input refers to the expenses for research and development of enterprises. It not only bestows enterprises the necessary resources to transform research projects into results [17], but also provides the basic guarantee for enterprises to undertake innovation activities [65], therefore it is essential for firms. As the most influential participants of enterprises, top managers have greater dominance and control over the resource allocation of corporate innovation projects [10]. Some studies have shown that, CEOs with academic experience tend to regard $R \& D$ investment as the standard to judge the success of the organization. Therefore, they have greater motivation and power to invest a lot of R\&D funds to pursue their technological vision for innovation [66]. In China, because most of the R\&D funds of universities and scientific research institutions come from government supports and subsidizes, researchers might be less sensitive to the efficiency of innovation input than their peers $[67,68]$. However, whether innovation input guarantees the smooth output of innovation achievements is still uncertain. Studies have indicated that innovation input is a double-edged sword [69]. Excessive innovation input may lead to 
an imbalance of resource allocation in the short term, which increases the innovation and business risks of enterprises $[67,70]$. Therefore, when the innovation input of enterprises is excessive, executives with accumulated professional knowledge and experience may be highly confident and more likely to make greater risky investment decisions [71,72], such as pursuing the quality rather than quantity of green innovation, or developing difficult technological innovation. Because this behavior is more difficult and riskier, the failure rate of green innovation will be higher, which will adversely affect the output of green innovation. Based on this discussion, the following hypothesis is presented:

Hypothesis 4 (H4). Innovation input weakens the relationship between TMT's academic experience and corporate green innovation output.

2.5. The Moderating Role of Green Innovation Output in the Correlation between Top Management Teams' Academic Experience and Firm Performance

Green innovation is the key to coordinate the contradiction between economic growth and environment sustainable development; therefore, it enjoys powerful policy support [8]. However, it is unclear whether the existing green innovation methods bring better economic or financial benefits to enterprises compared with the previous mode of innovation. Some studies believe that green innovation can bring competitive advantage to enterprises, which improves firm performance [73]. However, in recent years, some find a negative relationship between green innovation and enterprises' performance through data investigation and empirical research [74]. Some scholars pointed out that executives with higher education tend to pay more attention to the long-term benefits of enterprises [34], therefore, such executives are more willing to improve firms' competitiveness through exploratory innovation $[13,33]$. Similarly, in the context of green development, top executives with academic experience often pay more attention to green innovation, which they regard as an important opportunity to promote the sustainable development of enterprises [10]. Therefore, when the output of green innovation is high, they will pay more attention to the role of green innovation in the long-term development of enterprises, ignoring the improvement of short-term performance. In addition, because green innovation usually has a long investment return period, it may not improve firm performance in the short term $[20,21]$, on the contrary, it will incur additional R\&D costs, such as training and safety costs [75], resulting in the reduction of corporate financial performance. Therefore, green innovation output may negatively affect the role of TMT's academic experience in improving firm performance in the short term. Based on this discussion, the following hypothesis is proposed:

Hypothesis 5 (H5). Green innovation output weakens the relationship between TMT's academic experience and firm performance.

\subsection{Enterprise Ownership and Firm Performance}

In China, state-owned enterprises (SOEs) and non-state-owned enterprises (POEs) are in different institutional environments, so there are great differences in their business objectives [76]. For POEs, they are in the background of market-oriented economic system, so their purpose is usually to maximize the profits of enterprises [77]. However, stateowned enterprises are in the background of social and political systems, therefore, they may assume social responsibility as their main goal, rather than maximizing the profits of enterprises [78,79]. In addition, top executives of SOEs have both economic and political characteristics [80], the promotions of top executives in SOEs often depend on their political performance rather than firm performance [81]. Therefore, in the context of China's strong advocacy of green and sustainable development, executives in SOEs usually invest more resources in green innovation, and even fulfill governmental expectation at the expense of business motives, so as to achieve political promotion [82]. In this situation, green innovation not only consumes a lot of financial funds of SOEs, but the green innovation achievements of SOEs may be a "face project" and lack practical value [83]. To summarize, 
under such a management system, due to nonprofit motivation and political promotion, compared with POEs, the green innovation of SOEs not only brings additional financial burden to enterprises, but also difficult to improve firm performance, which further weaken the role of TMT's academic experience in improving firm performance in the short term. Based on this discussion, the following hypothesis is proposed:

Hypothesis 6 (H6). Compared with top managers with academic experience of nonSOEs, top managers with academic experience of SOEs inhibit the transformation of green innovation output to firm performance.

\section{Materials and Methods}

\subsection{Data and Sample}

The initial study sample includes all Chinese A-share companies listed on Shanghai and Shenzhen Stock Exchanges between 2009 and 2017. The personal information about TMT was manually collected from the annual reports and company websites. The green patent data and environmental regulation data are collected from the State Intellectual Property Office and China Environmental Statistical Yearbook, respectively, and other relevant data are from China Stock Market and Accounting Research database. The sampling process is as follows: first, we exclude some special industries and companies, such as financial insurance industry, because of their particularity objectives and financial indicators. We also exclude ST and *ST companies, because they often have outliers. Second, we excluded companies that lacked the necessary data for this study. Finally, the annual observation data of 12,881 observations were obtained from 2890 companies.

\subsection{Measures}

\subsubsection{Dependent Variables}

Green innovation output (GI). Based on the data availability and existing research methods of green innovation, corporate green innovation output is measured by the number of green innovation patent applications [84]. Specifically, owing to the lag between strategic decision and green innovation output, the natural logarithm of green patents is taken after adding 1 to their number and pushing them forward by 1 year [85].

Firm Performance (Tobin Q). Following earlier research methods, this study uses the total market value of the company exceeding the total asset value of the company to measure Tobin Q, which is often used to measure the performance of enterprises [59].

\subsubsection{Independent Variables}

Top management teams' academic experience (Aca TMT). The academic experience of top management teams refers $\mathrm{CEO}$, general manager, and deputy general manager, and others, who have engaged in scientific research work in universities or scientific research institutions [86]. Following earlier research methods, we first pick out the executives who have academic experience and then calculate their proportion in top management teams [12].

\subsubsection{Moderating Variables}

To explore the factors that positively affect top management teams' academic experience, environmental regulation, political connection and innovation input are considered. Following earlier studies, we use the proportion of environmental pollution control investment in GDP to measure environmental regulation (ER), and then divide it into 0 and 1 according to the median to measure its intensity [87]; We examine whether top executives have held or are currently holding government positions (PC); if the result is yes, it is 1 , otherwise 0 [58]. Moreover, we use the proportion of R\&D expenditure in total assets, which is often used to measure innovation input (RD) [67]. 


\subsubsection{Control Variables}

In this study, following earlier studies, we also control some other variables to eliminate alternative explanations $[37,67]$. First, at the TMT level, we controlled top management team size (TMT Size), top management teams' shareholding ratio (TMT Hold) and CEO duality (Duality) Second, at the board level, we controlled board size (Board) and board independence (Independence). At the firm level, we controlled leverage (Lev), operating income (Income), turnover rate of total assets (Turnover), firm size (Firm Size), enterprise growth (Growth) and the shareholding ratio of the largest shareholder (Top 1), Finally, to control unknown heterogeneity from the environment, we control the year and industry dummies. The definitions of the variables are shown in Table 1.

Table 1. Variable definition.

\begin{tabular}{|c|c|c|}
\hline Variable & Symbol & Description \\
\hline Green Innovation Output & GI & The natural logarithm of green patents \\
\hline Firm Performance & Tobin Q & $\begin{array}{l}\text { The total market value of the company exceeding the total asset value of } \\
\text { the company }\end{array}$ \\
\hline $\begin{array}{l}\text { Top management teams' } \\
\text { academic experience }\end{array}$ & Aca TMT & $\begin{array}{l}\text { The proportion of top executives with academic experience in top } \\
\text { management teams }\end{array}$ \\
\hline Environmental Regulation & ER & $\begin{array}{l}\text { The proportion of environmental pollution control investment in GDP, } \\
\text { and then divide it into } 0 \text { and } 1 \text { according to the median to measure its } \\
\text { intensity }\end{array}$ \\
\hline Political Connection & PC & $\begin{array}{l}\text { When top executives have held or are currently holding government } \\
\text { positions, it is } 1 \text {; otherwise, } 0\end{array}$ \\
\hline Innovation Input & $\mathrm{RD}$ & The proportion of R\&D expenditure in total assets \\
\hline Leverage & Lev & the proportion of total corporate liabilities to total corporate assets \\
\hline Firm Size & Firm Size & The natural logarithm of total assets at the end of year \\
\hline Enterprise Growth & Growth & annual sales growth rate of enterprises \\
\hline Turnover Rate of Total Assets & Turnover & The ratio of net sales revenue to total average assets \\
\hline Operating Income & Income & the natural logarithm of operating income at the end of year \\
\hline CEO Duality & Duality & When the CEO and chairperson is the same person, it is 1 ; otherwise, 0 \\
\hline TMT Size & TMT Size & The total number of top management team \\
\hline TMT Shareholding Ratio & TMT Hold & $\begin{array}{l}\text { The proportion of top management teams' shareholding in total shares of } \\
\text { the company }\end{array}$ \\
\hline $\begin{array}{l}\text { Largest Shareholder' } \\
\text { Shareholding Ratio }\end{array}$ & Top 1 & $\begin{array}{l}\text { The proportion of shares held by the largest shareholder in the total } \\
\text { number of shares held by all shareholders }\end{array}$ \\
\hline Board Size & Board & The total number of directors \\
\hline Board Independence & Independence & The proportion of independent directors in the total number of directors \\
\hline
\end{tabular}

\subsection{Regression Model}

This study uses the ordinary least square (OLS) regression analysis to test the research hypotheses, the regression model is as follows:

$$
\begin{aligned}
& \mathrm{GI}_{\mathrm{t}+1}=\alpha_{0}+\alpha_{1} \times \text { Aca } \mathrm{TMT}_{\mathrm{t}}+\alpha_{2} \times \text { Control Variables } t+\Sigma \text { Year }+\Sigma \text { Industry }+\varepsilon_{\mathrm{t}} \\
& \mathrm{GI}_{\mathrm{t}+1}=\alpha_{0}+\alpha_{1} \times \text { Aca TMT }_{\mathrm{t}}+\alpha_{2} \times \mathrm{PC}_{\mathrm{t}}+\alpha_{3} \times \text { Aca TMT }_{\mathrm{t}} \times \mathrm{PC}_{\mathrm{t}}+\alpha_{4} \\
& \times \text { Control Variables }_{\mathrm{t}}+\Sigma \text { Year }+\Sigma \text { Industry }+\varepsilon_{\mathrm{t}} \\
& \mathrm{GI}_{\mathrm{t}+1}=\alpha_{0}+\alpha_{1} \times \text { Aca TMT }_{\mathrm{t}}+\alpha_{2} \times \mathrm{RD}_{\mathrm{t}}+\alpha_{3} \times \text { Aca TMT }_{\mathrm{t}} \times \mathrm{RD}_{\mathrm{t}}+\alpha_{4} \\
& \times \text { Control Variables }_{\mathrm{t}}+\Sigma \text { Year }+\Sigma \text { Industry }+\varepsilon_{\mathrm{t}} \\
& \text { Tobin } \mathrm{Q}_{\mathrm{t}+1}=\alpha_{0}+\alpha_{1} \times \text { Aca } \mathrm{TMT}_{\mathrm{t}}+\alpha_{2} \times \mathrm{GI}_{\mathrm{t}}+\alpha_{3} \times \text { Aca } \mathrm{TMT}_{\mathrm{t}} \times \mathrm{GI}_{\mathrm{t}}+\alpha_{4} \\
& \times \text { Control Var iables } t+\Sigma \text { Year }+\Sigma \text { Industry }+\varepsilon_{t}
\end{aligned}
$$


In these models, model 1 was the basic OLS regression for the correlation between TMT's academic experience and green innovation output, which is used to test hypotheses 1 and 2. Based on model 1, in models 2 and 3, respectively, we added political connection, innovation input, and their interaction terms to test hypotheses 3 and 4. If the interaction term coefficient is significant, and the explanatory power of variables is significantly improved compared with the previous model which only contains control variables and main effects, it plays a moderating role in this relationship [88,89]. Model 4 tests the impact of green innovation output on the relationship between TMT's academic experience and corporate performance, which is used to test hypotheses 5 and 6.

\section{Results}

\subsection{Descriptive Statistics and Correlation Analysis}

Table 2 shows the descriptive statistics of all variables. The average and standard deviation of green patent are 3.23 and 18.03, respectively, which reveals that the number of green patent applications of Chinese listed companies is low, and the green innovation ability of each enterprise is different. Similarly, the mean and standard deviation of independent variable TMT's academic experience are 0.256 and 0.136 , respectively, which indicates that approximately $25.6 \%$ of TMT members have academic experience in China. Besides, the average, standard deviation, maximum, and minimum values of other variables in this study are all within reasonable limits.

Table 2. Descriptive statistics.

\begin{tabular}{lcccccc}
\hline & Variables & Obs. & Mean & S.D. & Min & Max \\
\hline 1 & Aca TMT & 12,881 & 0.256 & 0.136 & 0 & 0.625 \\
2 & GI & 12,881 & 3.230 & 18.030 & 0 & 646 \\
3 & Tobin Q & 12,881 & 2.119 & 1.261 & 0.893 & 8.457 \\
4 & PC & 12,881 & 0.566 & 0.496 & 0 & 1 \\
5 & RD & 12,881 & 0.022 & 0.018 & 0 & 0.1 \\
6 & ER & 12,881 & 0.527 & 0.499 & 0 & 1 \\
7 & Ownership & 12,881 & 0.288 & 0.453 & 0 & 1 \\
8 & Lev & 12,881 & 0.380 & 0.201 & 0.055 & 0.894 \\
9 & Firm Size & 12,881 & $1.04 \times 10^{10}$ & $3.79 \times 10^{10}$ & $2.19 \times 10^{8}$ & $5.61 \times 10^{11}$ \\
10 & Growth & 12,881 & 0.284 & 0.457 & -0.272 & 2.380 \\
11 & Turnover & 12,881 & 0.607 & 0.377 & 0.069 & 2.494 \\
12 & Income & 12,881 & $5.36 \times 10^{9}$ & $1.27 \times 10^{10}$ & $2.21 \times 10^{7}$ & $8.20 \times 10^{10}$ \\
13 & Duality & 12,881 & 0.306 & 0.461 & 0 & 1 \\
14 & TMT Size & 12,881 & 6.488 & 2.267 & 2 & 14 \\
15 & TMT Hold & 12,881 & 0.095 & 0.153 & 0 & 0.606 \\
16 & Top 1 & 12,881 & 0.349 & 0.144 & 0.089 & 0.752 \\
17 & Board & 12,881 & 8.589 & 1.631 & 5 & 15 \\
18 & Independence & 12,881 & 0.374 & 0.053 & 0.091 & 0.571 \\
\hline
\end{tabular}

We define enterprise ownership as a dummy variable. If enterprise ownership is state-owned, the value is 1 , otherwise 0 .

Table 3 shows the correlation of all variables used in this study. Among them, the coefficients of correlation matrices are all less than 0.7 , and the average value of variance expansion factor (VIF) is between 1 and 2, which is significantly lesser than 10, indicating no serious multiple collinearity problem. The VIF for regression analysis is not reported, but these data can be provided as needed. 
Table 3. Correlation of all variables.

\begin{tabular}{|c|c|c|c|c|c|c|c|c|c|c|c|c|c|c|c|c|c|}
\hline & Variables & 1 & 2 & 3 & 4 & 5 & 6 & 7 & 8 & 9 & 10 & 11 & 12 & 13 & 14 & 15 & 16 \\
\hline 1 & Aca TMT & 1 & & & & & & & & & & & & & & & \\
\hline 2 & GI & $\begin{array}{c}0.043 \\
* * *\end{array}$ & 1 & & & & & & & & & & & & & & \\
\hline 3 & Tobin Q & $\underset{* * *}{0.073}$ & $\underset{* * *}{-0.091}$ & 1 & & & & & & & & & & & & & \\
\hline 4 & PC & $\underset{* * *}{0.118}$ & 0.012 & $\underset{* * *}{-0.051}$ & 1 & & & & & & & & & & & & \\
\hline 5 & $\mathrm{RD}$ & $\underset{* * *}{0.134}$ & $\underset{* * *}{0.174}$ & $\underset{* * *}{0.245}$ & $\underset{* * *}{-0.088}$ & 1 & & & & & & & & & & & \\
\hline 6 & Lev & $\underset{* * *}{-0.131}$ & $\underset{* * *}{0.151}$ & $\underset{* * *}{-0.281}$ & $\underset{* * *}{0.035}$ & $\underset{* * *}{-0.219}$ & 1 & & & & & & & & & & \\
\hline 7 & Firm Size & $-\underset{* *}{0.020}$ & $\begin{array}{c}0.179 \\
* * *\end{array}$ & $-\underset{* * *}{0.160}$ & $\underset{* * *}{0.071}$ & $\underset{* * *}{-0.119}$ & $\underset{* * *}{0.272}$ & 1 & & & & & & & & & \\
\hline 8 & Growth & $\underset{* * *}{0.050}$ & -0.009 & $-\underset{* * *}{0.053}$ & 0.007 & 0.000 & $-\underset{* * *}{-0.188}$ & $-\underset{* * *}{-0.067}$ & 1 & & & & & & & & \\
\hline 9 & Turnover & $-\underset{* * *}{-0.075}$ & $0.017^{*}$ & $\underset{* * *}{-0.042}$ & 0.000 & $\underset{* * *}{0.111}$ & $\underset{* * *}{0.226}$ & $\underset{* * *}{0.030}$ & $-\underset{* * *}{-0.144}$ & 1 & & & & & & & \\
\hline 10 & Income & $\underset{* * *}{-0.114}$ & $\underset{* * *}{0.238}$ & $\underset{* * *}{-0.344}$ & $\underset{* * *}{0.056}$ & $\underset{* * *}{-0.142}$ & $\underset{* * *}{0.610}$ & $\underset{* * *}{0.475}$ & $-\underset{* * *}{0.203}$ & $\underset{* * *}{0.477}$ & 1 & & & & & & \\
\hline 11 & Duality & $\underset{* * *}{0.064}$ & $-\underset{* *}{-0.017}$ & $\underset{* * *}{0.042}$ & $\underset{* * *}{-0.048}$ & $\underset{* * *}{0.090}$ & $\underset{* * *}{-0.171}$ & $-\underset{* * *}{-0.086}$ & $\underset{* * *}{0.137}$ & $\underset{* * *}{-0.086}$ & $\underset{* * *}{-0.211}$ & 1 & & & & & \\
\hline 12 & TMT Size & $-\underset{* * *}{-0.116}$ & $\begin{array}{c}0.189 \\
* * *\end{array}$ & $\underset{* * *}{-0.094}$ & $\underset{* * *}{0.114}$ & $\underset{* * *}{0.031}$ & $\underset{* * *}{0.186}$ & $\underset{* * * *}{0.160}$ & $-\underset{* * *}{0.042}$ & $\underset{* * *}{0.030}$ & $\underset{* * *}{0.284}$ & $-\underset{* * *}{0.050}$ & 1 & & & & \\
\hline 13 & TMT Hold & $\underset{* * *}{0.110}$ & $-\underset{* * *}{-0.026}$ & $0.018^{* *}$ & $\underset{* * *}{-0.060}$ & $\underset{* * *}{0.145}$ & $\underset{* * *}{-0.303}$ & $-\underset{* * *}{0.129}$ & $\underset{* * *}{0.212}$ & $\underset{* * *}{-0.126}$ & $\underset{* * *}{-0.346}$ & $\underset{* * *}{0.512}$ & $\underset{* * *}{-0.062}$ & 1 & & & \\
\hline 14 & Top 1 & $\begin{array}{c}-0.017 \\
*\end{array}$ & $0.017^{*}$ & $\underset{* * *}{-0.063}$ & -0.004 & $\underset{* * *}{-0.108}$ & $\underset{* * *}{0.074}$ & $\underset{* * *}{0.170}$ & $-\underset{* * *}{-0.045}$ & $\underset{* * *}{0.117}$ & $\underset{* * *}{0.192}$ & $\underset{* *}{-0.019}$ & -0.006 & $\underset{* * *}{-0.043}$ & 1 & & \\
\hline 15 & Board & -0.013 & $\underset{* * *}{0.084}$ & $\underset{* * *}{-0.127}$ & $\underset{* * *}{0.104}$ & $-\underset{* * *}{-0.090}$ & $\underset{* * *}{0.201}$ & $\begin{array}{c}0.117 \\
* * *\end{array}$ & $-\underset{* * *}{0.073}$ & $\underset{* * *}{0.055}$ & $\begin{array}{c}0.276 \\
* * *\end{array}$ & $\underset{* * *}{-0.170}$ & $\begin{array}{c}0.238 \\
* * *\end{array}$ & $\begin{array}{c}-0.175 \\
* * *\end{array}$ & -0.009 & 1 & \\
\hline 16 & Independence & $\underset{* * *}{0.041}$ & 0.002 & $\underset{* * *}{0.031}$ & $\underset{* * *}{-0.044}$ & $\underset{* * *}{0.039}$ & $-\underset{* * *}{-0.024}$ & $\underset{* * *}{0.101}$ & 0.011 & $-\underset{* * *}{0.040}$ & $-\underset{* *}{0.018}$ & $\underset{* * *}{0.107}$ & $\underset{* * *}{-0.050}$ & $\underset{* * *}{0.109}$ & $\underset{* * *}{0.067}$ & $-\underset{* * *}{-0.494}$ & 1 \\
\hline
\end{tabular}




\subsection{Main Analysis}

\subsubsection{TMT's Academic Experience and Green Innovation Output}

Table 4 shows the regression results. In model 1 , the effect of TMT's academic experience on green innovation output is positive $(\beta=0.322, p<0.01)$, suggesting that TMT with academic experience promotes firms' green innovation output, thus supporting hypothesis 1 . In models 2 and 3, the effect of TMT's academic experience on green innovation output is positive but differs from that in model $2(\beta=0.360, p<0.01)$ and model $3(\beta=0.287, p<0.01)$. These results indicate that the positive impact of TMT's academic experience on green innovation output is strengthened under the strict environmental regulation than lenient ones. Thus, hypothesis 2 is supported.

Table 4. Ordinary least squats (OLS) regression of TMT's academic experience on lagging corporate green innovation output.

\begin{tabular}{|c|c|c|c|c|c|}
\hline Variables & $\begin{array}{l}\text { Model-1 } \\
\text { All }\end{array}$ & $\begin{array}{l}\text { Model-2 } \\
\text { Strict ER }\end{array}$ & $\begin{array}{c}\text { Model-3 } \\
\text { Lenient ER }\end{array}$ & $\begin{array}{l}\text { Model-4 } \\
\text { All }\end{array}$ & $\begin{array}{c}\text { Model-5 } \\
\text { All }\end{array}$ \\
\hline Lev & $\begin{array}{l}0.230 * * * \\
(-4.91)\end{array}$ & $\begin{array}{l}0.273^{* * *} \\
(-4.24)\end{array}$ & $\begin{array}{l}0.180 * * * \\
(-2.61)\end{array}$ & $\begin{array}{l}0.230 * * * \\
(-4.91)\end{array}$ & $\begin{array}{l}0.238^{* * *} \\
(-5.08)\end{array}$ \\
\hline Firm Size & $\begin{array}{l}-0.048 \\
(-1.59)\end{array}$ & $\begin{array}{c}0.008 \\
(-0.20)\end{array}$ & $\begin{array}{c}-0.143^{* * *} \\
(-3.03)\end{array}$ & $\begin{array}{l}-0.043 \\
(-1.43)\end{array}$ & $\begin{array}{l}-0.052 * \\
(-1.74)\end{array}$ \\
\hline Growth & $\begin{array}{l}0.053^{* * *} \\
(-3.23)\end{array}$ & $\begin{array}{l}0.048^{* *} \\
(-2.14)\end{array}$ & $\begin{array}{l}0.052^{* *} \\
(-2.21)\end{array}$ & $\begin{array}{l}0.053^{* * *} \\
(-3.28)\end{array}$ & $\begin{array}{l}0.050 * * * \\
(-3.10)\end{array}$ \\
\hline Turnover & $\begin{array}{c}-0.315^{* * *} \\
(-7.24)\end{array}$ & $\begin{array}{c}-0.413 * * * \\
(-7.43)\end{array}$ & $\begin{array}{l}-0.141 \text { * } \\
(-1.95)\end{array}$ & $\begin{array}{c}-0.322 * * * \\
(-7.37)\end{array}$ & $\begin{array}{c}-0.311^{* * *} \\
(-7.12)\end{array}$ \\
\hline Income & $\begin{array}{l}0.210^{* * *} \\
(-20.4)\end{array}$ & $\begin{array}{l}0.200^{* * *} \\
(-14.21)\end{array}$ & $\begin{array}{l}0.221 * * * \\
(-14.79)\end{array}$ & $\begin{array}{l}0.210^{* * *} \\
(-20.43)\end{array}$ & $\begin{array}{l}0.209^{* * *} \\
(-20.38)\end{array}$ \\
\hline Duality & $\begin{array}{c}0.003 \\
(-0.14)\end{array}$ & $\begin{array}{c}0.016 \\
(-0.65)\end{array}$ & $\begin{array}{l}-0.015 \\
(-0.55)\end{array}$ & $\begin{array}{c}0.002 \\
(-0.08)\end{array}$ & $\begin{array}{c}0.003 \\
(-0.15)\end{array}$ \\
\hline TMT Size & $\begin{array}{l}0.039 * * * \\
(-9.74)\end{array}$ & $\begin{array}{l}0.041^{* * *} \\
(-7.49)\end{array}$ & $\begin{array}{l}0.038^{* * *} \\
(-6.52)\end{array}$ & $\begin{array}{l}0.039 * * * \\
(-9.73)\end{array}$ & $\begin{array}{l}0.039^{* * *} \\
(-9.70)\end{array}$ \\
\hline TMT Hold & $\begin{array}{l}0.229^{* * *} \\
(-4.09)\end{array}$ & $\begin{array}{l}0.224^{* * *} \\
(-3.05)\end{array}$ & $\begin{array}{l}0.214^{* *} \\
(-2.44)\end{array}$ & $\begin{array}{l}0.229^{* * *} \\
(-4.08)\end{array}$ & $\begin{array}{l}0.229^{* * *} \\
(-4.09)\end{array}$ \\
\hline Top 1 & $\begin{array}{c}0.027 \\
(-0.48)\end{array}$ & $\begin{array}{l}-0.002 \\
(-0.03)\end{array}$ & $\begin{array}{c}0.038 \\
(-0.46)\end{array}$ & $\begin{array}{c}0.023 \\
(-0.41)\end{array}$ & $\begin{array}{c}0.030 \\
(-0.54)\end{array}$ \\
\hline Board & $\begin{array}{l}-0.0001 \\
(-0.02)\end{array}$ & $\begin{array}{l}-0.0105 \\
(-1.10)\end{array}$ & $\begin{array}{l}0.0077 \\
(-0.89)\end{array}$ & $\begin{array}{l}-0.0003 \\
(-0.05)\end{array}$ & $\begin{array}{l}0.0005 \\
(-0.07)\end{array}$ \\
\hline Independence & $\begin{array}{l}-0.165 \\
(-0.97)\end{array}$ & $\begin{array}{c}0.071 \\
(-0.30)\end{array}$ & $\begin{array}{l}-0.521^{* *} \\
(-2.17)\end{array}$ & $\begin{array}{l}-0.178 \\
(-1.05)\end{array}$ & $\begin{array}{l}-0.162 \\
(-0.96)\end{array}$ \\
\hline PC & $\begin{array}{l}-0.002 \\
(-0.12)\end{array}$ & $\begin{array}{l}-0.019 \\
(-0.89)\end{array}$ & $\begin{array}{c}0.020 \\
(-0.88)\end{array}$ & $\begin{array}{l}0.084^{* * *} \\
(-2.64)\end{array}$ & $\begin{array}{l}-0.002 \\
(-0.14)\end{array}$ \\
\hline $\mathrm{RD}$ & $\begin{array}{l}11.750^{* * *} \\
(-22.50)\end{array}$ & $\begin{array}{l}12.590^{* * *} \\
(-17.48)\end{array}$ & $\begin{array}{l}10.690 * * * \\
(-14.07)\end{array}$ & $\begin{array}{l}11.730^{* * * *} \\
(-22.52)\end{array}$ & $\begin{array}{l}14.550 * * * \\
(-14.17)\end{array}$ \\
\hline Aca TMT & $\begin{array}{l}0.322^{* * *} \\
(-5.50)\end{array}$ & $\begin{array}{l}0.360 * * * \\
(-4.50)\end{array}$ & $\begin{array}{l}0.287^{* * *} \\
(-3.33)\end{array}$ & $\begin{array}{l}0.523^{* * *} \\
(-5.92)\end{array}$ & $\begin{array}{l}0.571^{* * *} \\
(-6.52)\end{array}$ \\
\hline Aca TMT $\times$ PC & & & & $\begin{array}{l}-0.34^{* * *} \\
(-2.99)\end{array}$ & \\
\hline Aca $\mathrm{TMT} \times \mathrm{RD}$ & & & & & $\begin{array}{c}-10.67^{* * *} \\
(-3.29)\end{array}$ \\
\hline Year & Yes & Yes & Yes & Yes & Yes \\
\hline Industry & Yes & Yes & Yes & Yes & Yes \\
\hline Constant & $\begin{array}{l}-4.430 * * * \\
(-20.52)\end{array}$ & $\begin{array}{l}-4.109 * * * \\
(-13.94)\end{array}$ & $\begin{array}{l}-4.822 * * * \\
(-15.34)\end{array}$ & $\begin{array}{l}-4.469 * * * \\
(-20.66)\end{array}$ & $\begin{array}{c}-4.497^{* * *} \\
(-20.74)\end{array}$ \\
\hline Adjusted $\mathrm{R}^{2}$ & 0.1412 & 0.1365 & 0.1471 & 0.1418 & 0.1421 \\
\hline F-test ( $\mathrm{R}^{2}$ change) & - & 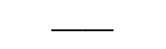 & - & $8.92^{* * *}$ & $10.80^{* * *}$ \\
\hline Observations & 12,881 & 6793 & 6088 & 12,881 & 12,881 \\
\hline
\end{tabular}


Models 4 and 5 added political connection, innovation input, and their interaction terms to test hypotheses 3 and 4 , respectively. In model 4 , the interaction between TMT's academic experience and political connection is negative $(\beta=-0.34, p<0.01)$, indicating that political connection weakens the positive correlation between TMT's academic experience and green innovation output. Moreover, compared with model 1 , the $\mathrm{R}^{2}$ of model 4 increases from 0.1412 to 0.1418 after Aca TMT $\times$ PC is added, and F-test reveals that the incremental increase in $R^{2}$ is significant. Thus, hypothesis 3 is supported. In model 5 , the interaction between TMT's academic experience and innovation input is negative $(\beta=-10.67, p<0.01)$, indicating that innovation input weakens the positive correlation between TMT's academic experience and green innovation output. Moreover, compared with model 1 , the $\mathrm{R}^{2}$ of model 5 increases from 0.1412 to 0.1421 after Aca TMT $\times$ RD is added, and F-test reveals that the incremental increase in $R^{2}$ is significant. Thus, hypothesis 4 is supported.

Figures 1 and 2, illustrates a regulatory effect diagram to better demonstrate this regulatory effect. Figure 1 shows that when top managers do not have political ties, the relationship between TMT's academic experience and green innovation output is positive and the slope is steep. Conversely, when they have political association, this relationship becomes less positive and the slope is flatter. The results show that political connection weakens the positive role of TMT's academic experience in promoting firms' green innovation output. Figure 2 shows that when the innovation input is low, the relationship between TMT's academic experience and green innovation output is positive and the slope is steep. Conversely, when innovation input is high, this relationship becomes less positive and the slope is flatter. The results show that innovation input weakens the positive role of TMT's academic experience in promoting firms' green innovation output, which are consistent with the theoretical expectations.

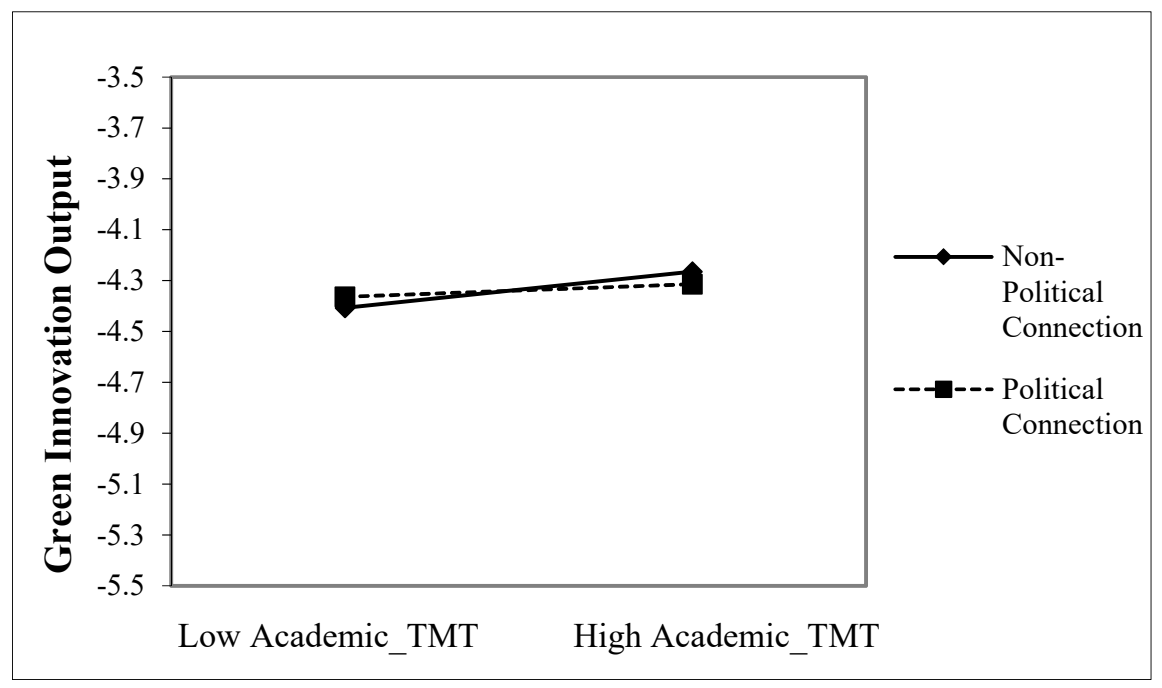

Figure 1. Moderating effects of political connection. 


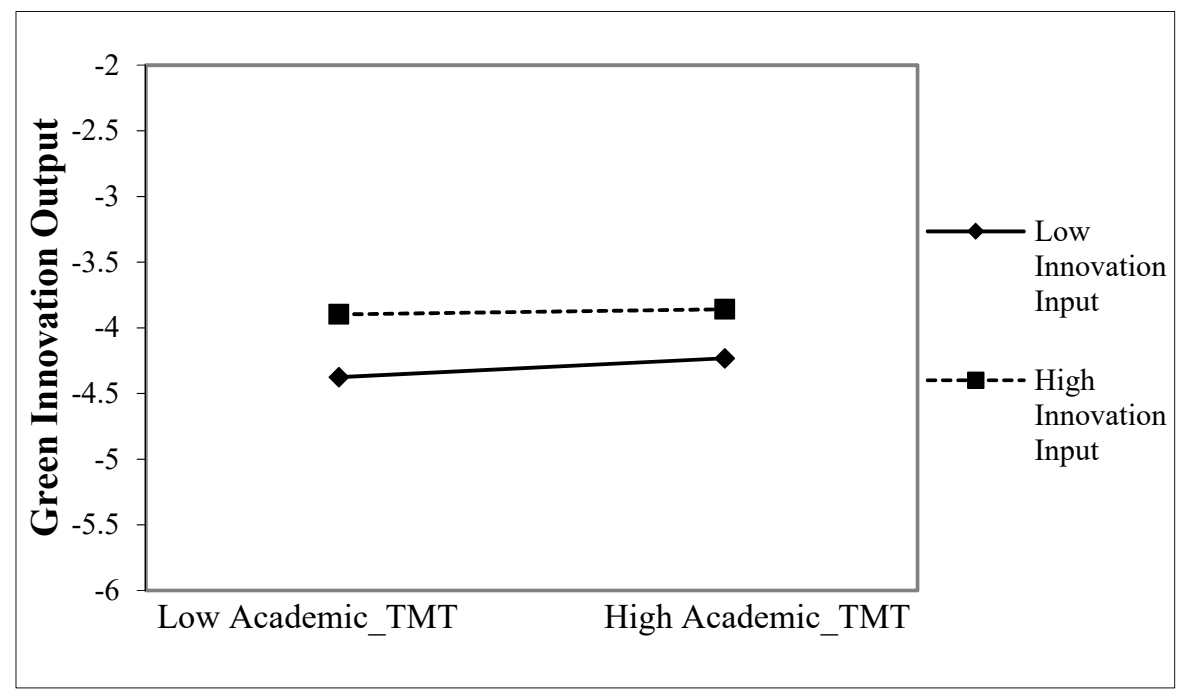

Figure 2. Moderating effects of Innovation Input.

4.2.2. TMT's Academic Experience, Green Innovation Output, and Firm Performance

Table 5 presents the moderating effect of green innovation output on the relationship between TMT's academic experience and firm performance. In model 6 , the effect of TMT's academic experience on firm performance is positive $(\beta=0.206, p<0.01)$, suggesting that TMT's academic experience positively promotes firm performance. In model 7 , the interaction between TMT's academic experience and green innovation output is negative ( $\beta=-0.219, p<0.01)$, indicating that green innovation output weakens the positive correlation between TMT's academic experience and firm performance. Moreover, compared with model 6, the $\mathrm{R}^{2}$ of model 7 increases from 0.3661 to 0.3665 after Aca TMT $\times \mathrm{GI}$ is added, and F-test reveals that the incremental increase in $R^{2}$ is significant. Thus, hypothesis 5 is supported. In models 8 and 9 , the inhibition effect of green innovation output of SOEs $(\beta=-0.262, p<0.05)$ is found to be more prominent than that of non-SOEs $(\beta=-0.170$, $p<0.05)$, indicating that SOEs are not effective at transforming innovative products into economic benefits. Thus, hypothesis 6 is supported.

Table 5. Ordinary least squats (OLS) regression of TMT's academic experience and green innovation on lagging firm performance.

\begin{tabular}{ccccc}
\hline Variables & $\begin{array}{c}\text { Model-6 } \\
\text { All }\end{array}$ & $\begin{array}{c}\text { Model-7 } \\
\text { All }\end{array}$ & $\begin{array}{c}\text { Model-8 } \\
\text { SOE }\end{array}$ & $\begin{array}{c}\text { Model-9 } \\
\text { Non-SOE }\end{array}$ \\
\hline Lev & $-0.783^{* * *}$ & $-0.772^{* * *}$ & $-1.025^{* * *}$ & $-0.633^{* * *}$ \\
& $(-11.72)$ & $(-11.58)$ & $(-9.21)$ & $(-7.61)$ \\
Firm Size & $0.194^{* * *}$ & $0.194^{* * *}$ & $0.268^{* * *}$ & $0.157^{* * *}$ \\
& $(-4.73)$ & $(-4.72)$ & $(-4.31)$ & $(-2.91)$ \\
Growth & $-0.162^{* * *}$ & $-0.162^{* * *}$ & $-0.153^{* * *}$ & $-0.150^{* * *}$ \\
& $(-8.06)$ & $(-8.06)$ & $(-2.64)$ & $(-6.94)$ \\
Turnover & $0.193^{* * *}$ & $0.181^{* * *}$ & 0.062 & $0.266^{* * *}$ \\
& $(-3.18)$ & $(-2.97)$ & $(-0.77)$ & $(-3.06)$ \\
Income & $-0.362^{* * *}$ & $-0.354^{* * *}$ & $-0.356^{* * * *}$ & $-0.363^{* * *}$ \\
& $(-28.28)$ & $(-26.93)$ & $(-17.27)$ & $(-20.24)$ \\
Duality & $0.086^{* * *}$ & $0.087^{* * *}$ & -0.078 & $0.126^{* * *}$ \\
& $(-3.72)$ & $(-3.75)$ & $(-1.58)$ & $(-4.90)$ \\
TMT Size & 0.005 & 0.007 & 0.008 & 0.003 \\
& $(-1.27)$ & $(-1.63)$ & $(-1.32)$ & $(-0.65)$ \\
\hline
\end{tabular}


Table 5. Cont.

\begin{tabular}{|c|c|c|c|c|}
\hline Variables & $\begin{array}{c}\text { Model-6 } \\
\text { All }\end{array}$ & $\begin{array}{c}\text { Model-7 } \\
\text { All }\end{array}$ & $\begin{array}{c}\text { Model-8 } \\
\text { SOE }\end{array}$ & $\begin{array}{c}\text { Model-9 } \\
\text { Non-SOE }\end{array}$ \\
\hline TMT Hold & $\begin{array}{c}-1.170 * * * \\
(-16.77)\end{array}$ & $\begin{array}{c}-1.163 * * * \\
(-16.67)\end{array}$ & $\begin{array}{l}2.458 * \\
(-1.84)\end{array}$ & $\begin{array}{c}-1.162^{* * *} \\
(-15.33)\end{array}$ \\
\hline Top 1 & $\begin{array}{c}0.081 \\
(-1.23)\end{array}$ & $\begin{array}{c}0.077 \\
(-1.17)\end{array}$ & $\begin{array}{c}0.170 \\
(-1.62)\end{array}$ & $\begin{array}{c}0.027 \\
(-0.32)\end{array}$ \\
\hline Board & $\begin{array}{c}0.002 \\
(-0.33)\end{array}$ & $\begin{array}{c}0.002 \\
(-0.26)\end{array}$ & $\begin{array}{c}0.011 \\
(-1.19)\end{array}$ & $\begin{array}{l}-0.015 \\
(-1.61)\end{array}$ \\
\hline Independence & $\begin{array}{l}0.764^{* * *} \\
(-3.91)\end{array}$ & $\begin{array}{l}0.749^{* * *} \\
(-3.84)\end{array}$ & $\begin{array}{l}0.729 * * \\
(-2.47)\end{array}$ & $\begin{array}{l}0.468 * \\
(-1.80)\end{array}$ \\
\hline PC & $\begin{array}{l}-0.038^{* *} \\
(-2.06)\end{array}$ & $\begin{array}{c}-0.039^{* *} \\
(-2.11)\end{array}$ & $\begin{array}{l}-0.031 \\
(-0.95)\end{array}$ & $\begin{array}{l}-0.041 \text { * } \\
(-1.84)\end{array}$ \\
\hline $\mathrm{RD}$ & $\begin{array}{l}11.150 * * * \\
(-14.91)\end{array}$ & $\begin{array}{l}11.550^{* * *} \\
(-14.93)\end{array}$ & $\begin{array}{l}6.283^{* * * *} \\
(-5.06)\end{array}$ & $\begin{array}{l}13.280^{* * * *} \\
(-13.93)\end{array}$ \\
\hline Aca TMT & $\begin{array}{l}0.206^{* * *} \\
(-2.88)\end{array}$ & $\begin{array}{l}0.336^{* * *} \\
(-3.87)\end{array}$ & $\begin{array}{l}0.609^{* * *} \\
(-3.79)\end{array}$ & $\begin{array}{l}0.217^{* *} \\
(-2.10)\end{array}$ \\
\hline GI & & $\begin{array}{c}0.015 \\
(-0.78)\end{array}$ & $\begin{array}{l}0.056^{*} \\
(-1.86)\end{array}$ & $\begin{array}{l}-0.013 \\
(-0.53)\end{array}$ \\
\hline Aca TMT $\times$ GI & & $\begin{array}{c}-0.219 * * * \\
(-3.53)\end{array}$ & $\begin{array}{c}-0.262^{* *} \\
(-2.36)\end{array}$ & $\begin{array}{c}-0.170 \text { ** } \\
(-2.23)\end{array}$ \\
\hline Year & Yes & Yes & Yes & Yes \\
\hline Industry & Yes & Yes & Yes & Yes \\
\hline Constant & $\begin{array}{l}10.010^{* * *} \\
(-38.55)\end{array}$ & $\begin{array}{l}9.814^{* * *} \\
(-36.84)\end{array}$ & $\begin{array}{c}10.190^{* * *} \\
(-23.99)\end{array}$ & $\begin{array}{c}10.040^{* * *} \\
(-26.59)\end{array}$ \\
\hline Adjusted $\mathrm{R}^{2}$ & 0.3661 & 0.3665 & 0.3844 & 0.3670 \\
\hline $\begin{array}{c}\text { F-test }\left(\mathrm{R}^{2}\right. \\
\text { change) }\end{array}$ & $\underline{-}$ & $12.49^{* * *}$ & $\underline{-}$ & 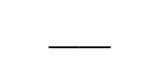 \\
\hline Observations & 12,881 & 12,881 & 3708 & 9173 \\
\hline
\end{tabular}

\subsection{Robustness Tests}

The robustness of the research model was established through additional analyses. Because of the lag effect of green innovation, the number of green patent applications with a lag of two years was used to measure green innovation and re-estimate the model. Table 6; Table 7 present the results of the robustness tests, which show that the effects of TMT's academic experience on green innovation output is positive $(\beta=0.394, p<0.01)$, and this impact is significant under strict environmental regulation $(\beta=0.508, p<0.01)$. Moreover, political connection $(\beta=-0.309, p<0.05)$ and innovation input $(\beta=-9.621$, $p<0.05)$ weakens the positive effect of TMT's academic experience on green innovation output. Green innovation output is also observed to have a negative impact on the relationship between TMT's academic experience and enterprise performance $(\beta=-0.170$, $p<0.05)$, and this negative impact is more significant in SOEs $(\beta=-0.316, p<0.05)$. All findings are consistent with the primary results. Therefore, the model is consistent with the robustness test.

Table 6. Robustness test 1.

\begin{tabular}{cccccc}
\hline \multirow{2}{*}{ Variables } & $\begin{array}{c}\text { Model-1 } \\
\text { All }\end{array}$ & $\begin{array}{c}\text { Model-2 } \\
\text { Strict ER }\end{array}$ & $\begin{array}{c}\text { Model-3 } \\
\text { Lenient ER }\end{array}$ & $\begin{array}{c}\text { Model-4 } \\
\text { All }\end{array}$ & $\begin{array}{c}\text { Model-5 } \\
\text { All }\end{array}$ \\
\hline Lev & $0.192^{* * *}$ & $0.215^{* * *}$ & $0.164^{* *}$ & $0.192^{* * *}$ & $0.200^{* * *}$ \\
& $(-3.57)$ & $(-2.80)$ & $(-2.15)$ & $(-3.57)$ & $(-3.71)$ \\
Firm Size & $-0.069^{* *}$ & -0.019 & $-0.149^{* * *}$ & $-0.064^{*}$ & $-0.074^{* *}$ \\
& $(-1.99)$ & $(-0.40)$ & $(-2.83)$ & $(-1.83)$ & $(-2.12)$ \\
Growth & $0.047^{* * *}$ & 0.036 & $0.055^{* *}$ & $0.048^{* * *}$ & $0.046^{* *}$ \\
& $(-2.63)$ & $(-1.40)$ & $(-2.14)$ & $(-2.67)$ & $(-2.51)$ \\
\hline
\end{tabular}


Table 6. Cont.

\begin{tabular}{|c|c|c|c|c|c|}
\hline Variables & $\begin{array}{c}\text { Model-1 } \\
\text { All }\end{array}$ & $\begin{array}{l}\text { Model-2 } \\
\text { Strict ER }\end{array}$ & $\begin{array}{c}\text { Model-3 } \\
\text { Lenient ER }\end{array}$ & $\begin{array}{c}\text { Model-4 } \\
\text { All }\end{array}$ & $\begin{array}{c}\text { Model-5 } \\
\text { All }\end{array}$ \\
\hline Turnover & $\begin{array}{c}-0.290 * * * \\
(-5.76)\end{array}$ & $\begin{array}{c}-0.379 * * * \\
(-5.76)\end{array}$ & $\begin{array}{l}-0.142 * \\
(-1.75)\end{array}$ & $\begin{array}{c}-0.297 * * * \\
(-5.88)\end{array}$ & $\begin{array}{c}-0.285^{* * *} \\
(-5.64)\end{array}$ \\
\hline Income & $\begin{array}{c}0.218^{* * *} \\
(-18.1)\end{array}$ & $\begin{array}{l}0.214^{* * *} \\
(-12.48)\end{array}$ & $\begin{array}{l}0.223^{* * *} \\
(-13.27)\end{array}$ & $\begin{array}{l}0.219^{* * *} \\
(-18.12)\end{array}$ & $\begin{array}{c}0.218^{* * *} \\
(-18.1)\end{array}$ \\
\hline Duality & $\begin{array}{c}0.019 \\
(-0.90)\end{array}$ & $\begin{array}{c}0.033 \\
(-1.14)\end{array}$ & $\begin{array}{c}0.004 \\
(-0.14)\end{array}$ & $\begin{array}{c}0.018 \\
(-0.86)\end{array}$ & $\begin{array}{c}0.019 \\
(-0.91)\end{array}$ \\
\hline TMT Size & $\begin{array}{l}0.036^{* * *} \\
(-7.95)\end{array}$ & $\begin{array}{l}0.036^{* * *} \\
(-5.68)\end{array}$ & $\begin{array}{l}0.037^{* * *} \\
(-5.70)\end{array}$ & $\begin{array}{c}0.036^{* * *} \\
(-7.94)\end{array}$ & $\begin{array}{l}0.036^{* * *} \\
(-7.92)\end{array}$ \\
\hline TMT Hold & $\begin{array}{l}0.217 * * * \\
(-3.38)\end{array}$ & $\begin{array}{l}0.248^{* * *} \\
(-2.82)\end{array}$ & $\begin{array}{l}0.174 * \\
(-1.84)\end{array}$ & $\begin{array}{l}0.217^{* * * *} \\
(-3.39)\end{array}$ & $\begin{array}{l}0.218^{* * *} \\
(-3.41)\end{array}$ \\
\hline Top 1 & $\begin{array}{l}-0.015 \\
(-0.23)\end{array}$ & $\begin{array}{l}-0.051 \\
(-0.56)\end{array}$ & $\begin{array}{c}0.002 \\
(-0.02)\end{array}$ & $\begin{array}{l}-0.018 \\
(-0.28)\end{array}$ & $\begin{array}{l}-0.012 \\
(-0.20)\end{array}$ \\
\hline Board & $\begin{array}{l}-0.006 \\
(-0.77)\end{array}$ & $\begin{array}{l}-0.017 \\
(-1.54)\end{array}$ & $\begin{array}{c}0.002 \\
(-0.20)\end{array}$ & $\begin{array}{l}-0.006 \\
(-0.80)\end{array}$ & $\begin{array}{l}-0.005 \\
(-0.70)\end{array}$ \\
\hline Independence & $\begin{array}{l}-0.187 \\
(-0.99)\end{array}$ & $\begin{array}{c}0.051 \\
(-0.18)\end{array}$ & $\begin{array}{l}-0.527^{* *} \\
(-2.05)\end{array}$ & $\begin{array}{l}-0.200 \\
(-1.06)\end{array}$ & $\begin{array}{l}-0.182 \\
(-0.97)\end{array}$ \\
\hline PC & $\begin{array}{l}-0.012 \\
(-0.71)\end{array}$ & $\begin{array}{l}-0.041 \\
(-1.67)\end{array}$ & $\begin{array}{c}0.019 \\
(-0.77)\end{array}$ & $\begin{array}{l}0.065 * \\
(-1.81)\end{array}$ & $\begin{array}{l}-0.013 \\
(-0.75)\end{array}$ \\
\hline $\mathrm{RD}$ & $\begin{array}{l}11.41^{* * *} \\
(-19.04)\end{array}$ & $\begin{array}{l}12.23^{* * *} \\
(-14.56)\end{array}$ & $\begin{array}{l}10.48^{* * *} \\
(-12.27)\end{array}$ & $\begin{array}{l}11.38^{* * *} \\
(-19.03)\end{array}$ & $\begin{array}{l}13.95^{* * *} \\
(-11.75)\end{array}$ \\
\hline Aca TMT & $\begin{array}{l}0.394^{* * *} \\
(-5.90)\end{array}$ & $\begin{array}{l}0.508^{* * *} \\
(-5.34)\end{array}$ & $\begin{array}{l}0.298^{* * *} \\
(-3.17)\end{array}$ & $\begin{array}{l}0.580^{* * *} \\
(-5.70)\end{array}$ & $\begin{array}{l}0.616^{* * *} \\
(-6.17)\end{array}$ \\
\hline $\begin{array}{c}\text { Aca TMT } \times \\
\text { PC }\end{array}$ & & & & $\begin{array}{c}-0.309^{* *} \\
(-2.38)\end{array}$ & \\
\hline $\begin{array}{c}\text { Aca TMT } \times \\
\text { RD }\end{array}$ & & & & & $\begin{array}{c}-9.621^{* *} \\
(-2.57)\end{array}$ \\
\hline Year & Yes & Yes & Yes & Yes & Yes \\
\hline Industry & Yes & Yes & Yes & Yes & Yes \\
\hline Constant & $\begin{array}{c}-4.532 * * * \\
(-18.18)\end{array}$ & $\begin{array}{c}-4.310^{* * *} \\
(-12.25)\end{array}$ & $\begin{array}{l}-4.788^{* * *} \\
(-13.64)\end{array}$ & $\begin{array}{c}-4.567 * * * \\
(-18.27)\end{array}$ & $\begin{array}{c}-4.597^{* * *} \\
(-18.35)\end{array}$ \\
\hline Adjusted $\mathrm{R}^{2}$ & 0.1357 & 0.1351 & 0.1369 & 0.1359 & 0.1360 \\
\hline $\begin{array}{c}\text { F-test }\left(\mathrm{R}^{2}\right. \\
\text { change })\end{array}$ & - & 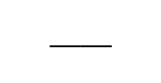 & - & 3.36 * & $7.87^{* * *}$ \\
\hline Observations & 9864 & 4862 & 5002 & 9864 & 9864 \\
\hline
\end{tabular}

Table 7. Robustness test 2.

\begin{tabular}{ccccc}
\hline Variables & Model-6 & Model-7 & Model-8 & Model-9 \\
& All & All & SOE & Non-SOE \\
\hline Lev & $-0.923^{* * * *}$ & $-0.912^{* * *}$ & $-1.081^{* * *}$ & $-0.761^{* * *}$ \\
& $(-11.80)$ & $(-11.69)$ & $(-8.99)$ & $(-7.49)$ \\
Firm Size & $0.162^{* * *}$ & $0.160^{* * *}$ & $0.232^{* * *}$ & $0.128^{* * *}$ \\
& $(-3.33)$ & $(-3.3)$ & $(-3.23)$ & $(-1.96)$ \\
Growth & $-0.279^{* * *}$ & $-0.277^{* * *}$ & $-0.305^{* * *}$ & $-0.247^{* * *}$ \\
& $(-13.31)$ & $(-13.25)$ & $(-5.27)$ & $(-10.83)$ \\
Turnover & $0.209^{* * *}$ & $0.199^{* * *}$ & 0.0741 & $0.303^{* * *}$ \\
& $(-2.93)$ & $(-2.78)$ & $(-0.73)$ & $(-3.03)$ \\
Income & $-0.385^{* * *}$ & $-0.377^{* * *}$ & $-0.366^{* * *}$ & $-0.396^{* * *}$ \\
& $(-25.47)$ & $(-24.25)$ & $(-15.86)$ & $(-18.06)$ \\
Duality & $0.114^{* * *}$ & $0.116^{* * *}$ & -0.070 & $0.159^{* * *}$ \\
& $(-4.12)$ & $(-4.16)$ & $(-1.37)$ & $(-5.00)$ \\
\hline
\end{tabular}


Table 7. Cont.

\begin{tabular}{|c|c|c|c|c|}
\hline Variables & $\begin{array}{c}\text { Model-6 } \\
\text { All }\end{array}$ & $\begin{array}{c}\text { Model-7 } \\
\text { All }\end{array}$ & $\begin{array}{l}\text { Model-8 } \\
\text { SOE }\end{array}$ & $\begin{array}{c}\text { Model-9 } \\
\text { Non-SOE }\end{array}$ \\
\hline TMT Size & $\begin{array}{c}0.007 \\
(-1.41)\end{array}$ & $\begin{array}{l}0.008 * \\
(-1.71)\end{array}$ & $\begin{array}{l}0.014^{*} \\
(-1.91)\end{array}$ & $\begin{array}{c}0.005 \\
(-0.78)\end{array}$ \\
\hline TMT Hold & $\begin{array}{c}-1.179 * * * \\
(-13.77)\end{array}$ & $\begin{array}{c}-1.171^{* * *} \\
(-13.66)\end{array}$ & $\begin{array}{l}4.137^{* * *} \\
(-2.88)\end{array}$ & $\begin{array}{c}-1.232 * * * \\
(-13.15)\end{array}$ \\
\hline Top 1 & $\begin{array}{l}0.343^{* * *} \\
(-4.44)\end{array}$ & $\begin{array}{l}0.340^{* * * *} \\
(-4.40)\end{array}$ & $\begin{array}{l}0.322^{* * *} \\
(-2.82)\end{array}$ & $\begin{array}{l}0.349^{* * *} \\
(-3.39)\end{array}$ \\
\hline Board & $\begin{array}{c}0.003 \\
(-0.37)\end{array}$ & $\begin{array}{c}0.002 \\
(-0.29)\end{array}$ & $\begin{array}{c}0.010 \\
(-0.90)\end{array}$ & $\begin{array}{l}-0.010 \\
(-0.86)\end{array}$ \\
\hline Independence & $\begin{array}{l}0.780^{* * *} \\
(-3.48)\end{array}$ & $\begin{array}{l}0.763^{* * *} \\
(-3.40)\end{array}$ & $\begin{array}{c}0.651^{*} \\
(-1.93)\end{array}$ & $\begin{array}{l}0.602^{* *} \\
(-2.04)\end{array}$ \\
\hline PC & $\begin{array}{l}-0.050^{* *} \\
(-2.26)\end{array}$ & $\begin{array}{l}-0.051^{* *} \\
(-2.32)\end{array}$ & $\begin{array}{l}-0.006 \\
(-0.17)\end{array}$ & $\begin{array}{c}-0.073^{* * *} \\
(-2.67)\end{array}$ \\
\hline RD & $\begin{array}{l}10.510 * * * \\
(-12.14)\end{array}$ & $\begin{array}{l}10.920^{* * *} \\
(-12.18)\end{array}$ & $\begin{array}{l}5.717^{* * *} \\
(-4.16)\end{array}$ & $\begin{array}{c}12.710^{* * *} \\
(-11.28)\end{array}$ \\
\hline Aca TMT & $\begin{array}{l}0.211^{* *} \\
(-2.50)\end{array}$ & $\begin{array}{l}0.323^{* * *} \\
(-3.11)\end{array}$ & $\begin{array}{l}0.641^{* * *} \\
(-3.57)\end{array}$ & $\begin{array}{c}0.151 \\
(-1.19)\end{array}$ \\
\hline GI & & $\begin{array}{c}0.004 \\
(-0.19)\end{array}$ & $\begin{array}{l}0.069^{* *} \\
(-2.01)\end{array}$ & $\begin{array}{l}-0.035 \\
(-1.26)\end{array}$ \\
\hline $\begin{array}{c}\text { Aca TMT } \\
\text { GI }\end{array}$ & & $\begin{array}{c}-0.170^{* *} \\
(-2.38)\end{array}$ & $\begin{array}{l}-0.316^{* *} \\
(-2.56)\end{array}$ & $\begin{array}{l}-0.081 \\
(-0.91)\end{array}$ \\
\hline Year & Yes & Yes & Yes & Yes \\
\hline Industry & Yes & Yes & Yes & Yes \\
\hline Constant & $\begin{array}{l}9.591 * * * \\
(-32.77)\end{array}$ & $\begin{array}{l}9.399^{* * *} \\
(-31.2)\end{array}$ & $\begin{array}{l}9.431^{* * *} \\
(-21.41)\end{array}$ & $\begin{array}{l}9.764^{* * *} \\
(-21.62)\end{array}$ \\
\hline Adjusted $\mathrm{R}^{2}$ & 0.3730 & 0.3731 & 0.3892 & 0.3702 \\
\hline $\begin{array}{c}\text { F-test }\left(\mathrm{R}^{2}\right. \\
\text { change) }\end{array}$ & 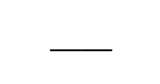 & $4.66^{* *}$ & - & 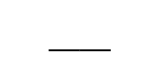 \\
\hline Observations & 9864 & 9864 & 2945 & 6919 \\
\hline
\end{tabular}

Robust standard errors in parentheses. ${ }^{* * *} p<0.01$; $^{* *} p<0.05 ;{ }^{*} p<0.1$.

\section{Discussion}

In the context of global advocacy of coordinated development between economy and environment, green innovation is considered the key for firms' survival and for sustainability to develop. Therefore, it is important to explore the driving factors of corporate green innovation. As the core of corporate governance, executives play an important role in promoting green innovation. The existing literature have discussed the impact of executives' gender, hubris, hometown identity and other characteristics on corporate green innovation. As a unique and important experience of executives, academic background has an important impact on corporate decision-making. However, the discussion of this unique experience in the existing literature is still limited. Therefore, based on the upper-echelon theory and taking Chinese listed companies as research samples, this paper discusses the impact of the unique academic background of top management team on corporate green innovation output and the moderating role of environmental regulation, political connection, and innovation input. It is found that top executives, who have academic background, promote the corporate green innovation output. Specifically, academic experience not only cultivates their spirit to explore new ideas and technologies, but also eases their sensitivity of innovation risk, which improves their tolerance for innovation failure. Moreover, scholars often have higher moral and social responsibility than others, which promotes the smooth development of green innovation strategy.

In addition, the promotion effect of top executives with academic experience on green innovation output is not uniform. Rather, it is affected by the boundary conditions. This study examines the influence of three boundary conditions: environmental regulation, political connection and innovation input. Compared with lenient environmental regulation, strict regulation can make top executives with academic experience focus on reducing 
environmental pollution and winning long-term competitive advantage for enterprises. Therefore, environmental regulation enhances the promotion of top executives with academic experience to green innovation output. Furthermore, unlike previous studies, this study finds that political connection and innovation input weakens the positive effect of top executives with academic experience on green innovation output. Political connection leads to rent-seeking cost and excessive control of government on firms' decision-making, which reduces the decision-making flexibility of TMT. Excessive innovation input impedes firms' long-term development, it no value to the implementation of green innovation strategy.

Finally, this study verifies whether green innovation improves the financial performance of enterprises with top executives who have academic experience. Although entrepreneurs are expected to improve environmental problems and earn high profits through green innovation [90], the empirical results show that green innovation output impedes the promotion of top executives with academic experience to firm performance because of several reasons. On the one hand, in the long run, green innovation activities help enterprises gain competitive advantage and improve firm performance, so this advantage cannot be reflected in the short run. On the other hand, most green innovative enterprises still lack the necessary conditions or ability to improve their performance, which cannot transform the green innovation achievements into economic benefits. Furthermore, this negative impact is more prominent in SOEs, because, in China, there are differences between SOEs and non-SOEs in business objectives. Owing to the long-term dependence on government protection, SOEs do not face the pressure of survival. They have advantages in terms of talent acquisition, funds, and other resources, which make them insensitive to firm performance. In addition, there is a serious agency problem in SOEs. The goal of enterprise owners is to maximize benefits of enterprises, while that of enterprise managers is to achieve personal benefits and political promotion, which is not directly linked with performance but depends on their own political performance. Therefore, these conflicts have a negative impact on the firm performance.

\section{Managerial Implication}

This study makes several important contributions to theory and managerial practice. Theoretically, first, this study enriches the upper-echelon theory. Several studies have showed that TMT's personal characteristics have a significant impact on firms' strategic decision-making. Studies have mostly focused on top executives' gender, hubris, hometown identity, and so on. However, there is a lack of research on their special academic background. This study systematically examines the influence of TMT's academic background on corporate strategic decision-making, which is helpful for the development of the upper-echelon theory. Second, this study enriches the literature on the antecedents influencing enterprises' green innovation activities. Several studies exist on green innovation. However, most are from the external environment perspective, ignoring the important role of internal factors. As an important strategy of enterprises, green innovation depends on TMT's choice preference. Hence, this study introduces the upper-echelon perspective into the issue of green innovation, which helps understand the internal driving force of enterprises' green innovation and the existing research on green innovation. Third, this study enriches the relevant literature on the firm performance. So far, there is no consensus on whether green innovation output promotes firm performance. Therefore, from the executives' unique background perspective, this study discusses whether green innovation improves the financial performance of enterprises with top executives who have academic experience, which provides an empirical basis for the existing research.

Moreover, in terms of management practice, first, the study results have certain practical significance to promote the implementation of sustainable development strategy. In the context of global low carbon development, green innovation is the key to achieve sustainable development. Therefore, it is necessary and urgent to find the driving force of green innovation. In China, many enterprises are employing executives with an academic background because they have a strong sense of innovation and high social responsibility, 
which effectively guides enterprises to embark on the journey of sustainable development and obtain long-term competitive advantage. Therefore, enterprises should select and motivate such executives to provide vitality for enterprises to undertake green innovation activities. Second, this study plays a warning role in the development of SOEs. Influenced by the nature of the enterprise and goal of political promotion, SOE executives often focus on their own political promotion rather than maximizing enterprises' profit, which shows the existence of problems in the current management mechanism. Therefore, the government should deepen the SOE reform and adjust the existing incentive mechanism. Considering the innovation achievements, improvement of business performance and contribution to ecological environment protection are important assessment objectives to alleviate the serious agency problem of SOEs and promote SOEs to improve enterprise efficiency and achieve rapid development.

\section{Conclusions}

This study focused on Chinese listed companies to discuss the impact of TMT's unique working background, that is, academic background, on firms' green innovation output. We also explored three boundary conditions that affect the role of TMT's academic experience. Furthermore, we tested the impact of green innovation output on top executives with academic experience and firm performance. The study found that the top executives with academic experience effectively promote the green innovation output of enterprises. Compared with the lenient environment regulations, strict regulations enhance the promotion effect of top executives' academic experience on green innovation output. However, political connection and innovation input weakens this positive relationship. Moreover, this study finds that green innovation output weakens the promotion effect of top executives with academic experience on firm performance, and this negative effect is more significant in state-owned enterprises. This study is of great significance and value to promote enterprises to implement green innovation strategy. At the same time, it has the following contributions to the existing research. First, it enriches the literature of the upper-echelon theory. Unlike the literature on the influence of TMT members' personal characteristics on corporate decision from the perspective of gender, hubris, hometown identity, and others, this study discusses the impact of TMT's unique functional background on corporate high-risk strategic decision-making, which supplements the existing research. Second, this paper studies the motivation of green technology innovation from the perspective of corporate internal management, which enriches the literature of green innovation. Previous studies have discussed the influence of external factors on firms' green innovation while ignoring the significance of internal governance factors. This study focuses on the unique working background of TMT for the first time, that is, the relationship between TMT's academic background and corporate green innovation, which adds a fresh perspective to literature. Third, it focuses on the economic consequences of enterprises. There is an ongoing debate on whether green innovation output can produce good economic benefits. Based on the TMT perspective, this study discusses whether green innovation output can lead to better economic benefits by enterprises with top executives who have academic experience and provides empirical evidence for the existing research.

Despite the potential contributions by this study, there are still some shortcomings. First, this study only considers the quantity of green innovation output, but not the quality. Future studies can address this limitation. Second, this study focuses on the impact of TMT's special work background on green innovation output and firm performance. However, several reasons explain why executives influence corporate strategy, but it is not comprehensive enough to explain the influence of TMT's characteristics on corporate strategic decision-making from a single perspective. Therefore, future studies should expand the research on TMT's other personal characteristics to improve the explanatory power of the research. Third, due to data limitations, this paper has not studied the longterm impact of green innovation on economic consequences, so future research should supplement this content. 
Author Contributions: Conceptualization, B.Z. and S.Z.; formal analysis, B.Z. and S.W.; resources, S.Z.; data curation, B.Z. and D.S.; writing-original draft preparation, B.Z.; writing-review and editing, S.Z. and D.S.; supervision, S.Z. All authors have read and agreed to the published version of the manuscript.

Funding: This research was supported by the National Key R\&D Program of China, grant number 2017YFB1401800, and the Key Consulting and Research Projects of Chinese Academy of Engineering, grant number 2020-JL-10.

Institutional Review Board Statement: Not applicable.

Informed Consent Statement: Not applicable.

Data Availability Statement: The data presented in this study are available on request from the corresponding author.

Acknowledgments: We would like to thank Haiqing Yu at Jilin University for providing valuable suggestions and writing assistance. Also, we would like to thank Hong Jiang at Jilin University for providing guidance on methods.

Conflicts of Interest: The authors declare no conflict of interest.

\section{References}

1. Zhang, D.; Rong, Z.; Ji, Q. Green innovation and firm performance: Evidence from listed companies in China. Resour. Conserv. Recycl. 2019, 144, 48-55. [CrossRef]

2. Inoue, E.; Arimura, T.; Nakano, M. A new insight into environmental innovation: Does the maturity of environmental management systems matter? Ecol. Econ. 2013, 94, 156-163. [CrossRef]

3. Duque-Grisales, E.; Aguilera-Caracuel, J.; Guerrero-Villegas, J.; García-Sánchez, E. Does green innovation affect the financial performance of Multilatinas? The moderating role of ISO 14001 and R\&D investment. Bus. Strat. Environ. 2020, 29, 3286-3302. [CrossRef]

4. Veugelers, R. Which policy instruments to induce clean innovating? Res. Policy 2012, 41, 1770-1778. [CrossRef]

5. Chang, C.-H. The Influence of Corporate Environmental Ethics on Competitive Advantage: The Mediation Role of Green Innovation. J. Bus. Ethic 2011, 104, 361-370. [CrossRef]

6. Woon-Leong, L.; Jun-Hwa, C.; Mohamed, A.; Ann, H.J. Does firm size matter? Evidence on the impact of the green innovation strategy on corporate financial performance in the automotive sector. J. Clean. Prod. 2019, 229, 974-988.

7. $\mathrm{Wu}, \mathrm{H} . ; \mathrm{Hu}, \mathrm{S}$. The impact of synergy effect between government subsidies and slack resources on green technology innova-tion. J. Clean. Prod. 2020, 274, 122682. [CrossRef]

8. Dangelico, R.M. Green Product Innovation: Where we are and Where we are Going. Bus. Strat. Environ. 2015, 25, 560-576. [CrossRef]

9. Wang, C.; Hu, Y.; Zhang, J.; Miao, C. CEO Media Exposure and Green Technological Innovation Decision: Evidence from Chi-nese Polluting Firms. Math. Probl. Eng. 2020. [CrossRef]

10. Ma, Z.; Zhang, H.; Zhong, W.; Zhou, K. Top Management Teams' Academic Experience and Firms' Corporate Social Responsibility Voluntary Disclosure. Manag. Organ. Rev. 2020, 16, 293-333. [CrossRef]

11. Donald, C.; Hambrick, P.; Mason, A. Upper Echelons: The Organization as a Reflection of Its Top Managers. Acad. Manag. Rev. 1984, 9, 193-206.

12. Shen, H.; Lan, F.; Xiong, H.; Lv, J.; Jian, J. Does top management Team's academic experience promote corporate innovation? Evidence from China. Econ. Model. 2019, 89, 464-475. [CrossRef]

13. Lee, C.; Park, G.; Marhold, K.; Kang, J. Top management team's innovation-related characteristics and the firm's explorative R\&D: An analysis based on patent data. Scientometrics 2017, 111, 639-663. [CrossRef]

14. Rugman, A.M.; Verbeke, A. Corporate Strategy and International Environmental Policy. J. Int. Bus. Stud. 1998, 29, 819-833. [CrossRef]

15. Adomako, S.; Danso, A. Regulatory environment, environmental dynamism, political ties, and performance: Study of entrepreneurial firms in a developing economy. J. Small Bus. Enterp. Dev. 2014, 21, 212-230. [CrossRef]

16. David, M.; Sinclair-Desgagné, B. Pollution Abatement Subsidies and the Eco-Industry. Environ. Resour. Econ. 2010, 45, 271-282. [CrossRef]

17. Diéguez-Soto, J.; Manzaneque, M.; Rojo-Ramírez, A. Technological Innovation Inputs, Outputs, and Performance: The Moderating Role of Family Involvement in Management. Fam. Bus. Rev. 2016, 29, 327-346. [CrossRef]

18. Berrone, P.; Fosfuri, A.; Gelabert, L.; Gomez-Mejia, L. Necessity as the mother of 'green' inventions: Institutional pres sures and environmental innovations. Strateg. Manag. J. 2013, 34, 891-909. [CrossRef]

19. Frondel, M.; Horbach, J.; Rennings, K. What triggers environmental management and innovation? Empirical evidence for Germany. Ecol. Econ. 2008, 66, 153-160. [CrossRef] 
20. Rennings, K. Redefining innovation-eco-innovation research and the contribution from ecological economics. Ecol. Econ. 2000, 32, 319-332. [CrossRef]

21. Adams, R.; Jeanrenaud, S.; Bessant, J.; Denyer, D.; Overy, P. Sustainability-oriented Innovation: A Systematic Review. Int. J. Manag. Rev. 2015, 18, 180-205. [CrossRef]

22. Smith, K.G.; Olian, J.D.; Sims, H.P.; O’Bannon, D.P.; Scully, J.A. Top Management Team Demography and Process: The Role of Social Integration and Communication. Adm. Sci. Q. 1994, 39, 412. [CrossRef]

23. Arena, C.; Michelon, G.; Trojanowski, G. Big Egos Can Be Green: A Study of CEO Hubris and Environmental Innovation. Br. J. Manag. 2017, 29, 316-336. [CrossRef]

24. Galbreath, J. Drivers of Green Innovations: The Impact of Export Intensity, Women Leaders, and Absorptive Capacity. J. Bus. Ethic 2017, 158, 47-61. [CrossRef]

25. Ren, S.; Wang, Y.; Hu, Y.; Yan, J. CEO hometown identity and firm green innovation. Bus. Strat. Environ. 2020, 30, 756-774. [CrossRef]

26. Balkin, D. Is CEO Pay in High-Technology Firms Related to Innovation? Acad. Manag. J. 2000, 43, 1118-1129. [CrossRef]

27. Jiang, B.; Murphy, P. Do business school professors make good executive managers? Acad. Manag. Perspect. 2007, 21, 29-50. [CrossRef]

28. Chen, J.; Nadkarni, S. Bridging yesterday, today, and tomorrow: CEO temporal focus, environmental dynamism, and rate of new product introduction. Acad. Manag. J. 2014, 57, 1810-1833.

29. Bantel, K.A.; Jackson, S.E. Top management and innovations in banking: Does the composition of the top team make a difference? Strateg. Manag. J. 1989, 10, 107-124. [CrossRef]

30. Kaplan, S.; Tripsas, M. Thinking about technology: Applying a cognitive lens to technical change. Res. Policy 2008, 37, 790-805. [CrossRef]

31. Berson, Y.; Oreg, S.; Dvir, T. CEO values, organizational culture and firm outcomes. J. Organ. Behav. 2008, 29, 615-633. [CrossRef]

32. Eggers, J.P.; Kaplan, S. Cognition and Renewal: Comparing CEO and Organizational Effects on Incumbent Adaptation to Technical Change. Organ. Sci. 2009, 20, 461-477. [CrossRef]

33. Beverly, B.; Tyler, H.; Kevin, S. The Effects of Executives' Experiences and Perceptions on Their Assessment of Poten-tial Technological Alliances. Strateg. Manag. J. 1986, 19, 939-965.

34. Lindberg, M.E. Student and early career mobility patterns among highly educated people in Germany, Finland, Italy, and the United Kingdom. High. Educ. 2009, 58, 339-358. [CrossRef]

35. March, J.G.; Shapira, Z. Managerial Perspectives on Risk and Risk Taking. Manag. Sci. 1987, 33, 1404-1418. [CrossRef]

36. March, J.G. Variable risk preferences and adaptive aspirations. J. Econ. Behav. Organ. 1988, 9, 5-24. [CrossRef]

37. Tian, X.; Wang, T.Y. Tolerance for Failure and Corporate Innovation. Rev. Financ. Stud. 2011, 27, 211-255. [CrossRef]

38. Charles HCho Jay, H.J.; Kwak, B.; Lee, J.; Yoo, C.Y. Professors on the board: Do they contribute to society outside the classroom? J. Bus. Ethics 2017, 141, 393-409.

39. Zhou, M.; Chen, F.; Chen, Z. Can CEO education promote environmental innovation: Evidence from Chinese enterprises. J. Clean. Prod. 2021, 297, 126725. [CrossRef]

40. Li, D.; Tang, F.; Jiang, J. Does environmental management system foster corporate green innovation? The moderating effect of environmental regulation. Technol. Anal. Strat. Manag. 2019, 31, 1242-1256. [CrossRef]

41. Camisón-Zornoza, C.; Boronat-Navarro, M. Does Regulation Perform Better Than Self-Regulation? An Analysis of Spanish Environmental Policies. Environ. Plan. C Gov. Policy 2010, 28, 733-758. [CrossRef]

42. Bao, H.; Wang, H.; Sun, C. How and when environmental regulation induces middle managers' proactive behavior. Career Dev. Int. 2019, 24, 438-452. [CrossRef]

43. Jiang, Z.Y.; Wang, Z.J.; Zeng, Y.Q. Can voluntary environmental regulation promote corporate technological innovation? Bus. Strategy Environ. 2020, 29, 390-406. [CrossRef]

44. Hu, D.; Wang, Y.; Huang, J.; Huang, H. How do different innovation forms mediate the relationship between environmental regulation and performance? J. Clean. Prod. 2017, 161, 466-476. [CrossRef]

45. Norberg-Bohm, V.; Rossi, M. The power of incrementalism: Environmental regulation and technological change in pulp and paper bleaching in the US. Technol. Anal. Strat. Manag. 1998, 10, 225-245. [CrossRef]

46. Chen, $\mathrm{H}$. The driving effect of internal and external environment on green innovation strategy-The moderating role of top management's environmental awareness. Nankai Bus. Rev. Int. 2019, 10, 342-361.

47. Qi, G.; Zou, H.; Xie, X. Governmental inspection and green innovation: Examining the role of environmental capability and institutional development. Corp. Soc. Responsib. Environ. Manag. 2020, 27, 1774-1785. [CrossRef]

48. Ha Ckner, J.; Herzing, M. The effectiveness of environmental inspections in oligopolistic markets. Resour. Energy Econ. 2017, 48, 83-97. [CrossRef]

49. Ramanathan, R.; He, Q.; Black, A.; Ghobadian, A.; Gallear, D. Environmental regulations, innovation and firm performance: A revisit of the Porter hypothesis. J. Clean. Prod. 2017, 155, 79-92. [CrossRef]

50. Porter, M.E.; Van der Linde, C. Toward a New Conception of the Environment-Competitiveness Relationship. J. Econ. Perspect. 1995, 9, 97-118. [CrossRef]

51. Faccio, M. Politically Connected Firms. Am. Econ. Rev. 2006, 96, 369-386. [CrossRef] 
52. Liu, S.; Du, J.; Zhang, W.; Tian, X.; Kou, G. Innovation quantity or quality? The role of political connections. Emerg. Mark. Rev. 2021, 48, 100819. [CrossRef]

53. Wang, S.; Zhao, S.K.; Shao, D.; Liu, H.Y. Impact of Government Subsidies on Manufacturing Innovation in China: The Moderat-ing Role of Political Connections and Investor Attention. Sustainability 2020, 12, 7740. [CrossRef]

54. Wong, W.; Hooy, C. Do types of political connection affect firm performance differently? Pac. Basin Financ. J. 2018, 51, 297-317. [CrossRef]

55. Faccio, M.; McConnell, R. Political Connections and Corporate Bailouts. J. Financ. 2006, 61, 2597-2635. [CrossRef]

56. Zhang, F.; Yang, L.; Zhou, G. Impact of Political Connections on Corporate Environmental Performance: From a Green Development Perspective. Sustainability 2019, 11, 1317. [CrossRef]

57. Lin, H.; Zeng, S.; Ma, H.; Chen, H. Does commitment to environmental self-regulation matter? An empirical examination from China. Manag. Decis. 2015, 53, 932-956. [CrossRef]

58. Huang, M.; Li, M.; Liao, Z. Do politically connected CEOs promote Chinese listed industrial firms' green innovation? The mediating role of external governance environments. J. Clean. Prod. 2021, 278, 123634. [CrossRef]

59. Hou, Q.; Hu, M.; Yuan, Y. Corporate innovation and political connections in Chinese listed firms. Pac.-Basin Financ. J. 2017, 46, 158-176. [CrossRef]

60. Cho, C.; Patten, D.; Roberts, R. Corporate Political Strategy: An Examination of the Relation between Political Ependitures, Environmental Performance, and Environmental Disclosure. J. Bus. Ethics 2006, 67, 139-154. [CrossRef]

61. Chen, C.J.; Li, Z.; Su, X.; Sun, Z. Rent-seeking incentives, corporate political connections, and the control structure of private firms: Chinese evidence. J. Corp. Financ. 2011, 17, 229-243. [CrossRef]

62. Wang, X.; Wang, L. State-Enterprise Relation, Local Economic Priority, and Corporate Environmental Responsibility. Appl. Econ. 2019, 51, 995-1009. [CrossRef]

63. Zhang, J.; Li, X.; Fung, H.; Qiao, P. Do Political Connections Promote Innovation in Environmentally Polluting Enterprises? China World Econ. 2019, 27, 76-101. [CrossRef]

64. Girma, S.; Gong, Y.; Görg, H. What Determines Innovation Activity in Chinese State-owned Enterprises? The Role of Foreign Direct Investment. World Dev. 2009, 37, 866-873. [CrossRef]

65. Schmid, T.; Achleitner, A.-K.; Ampenberger, M.; Kaserer, C. Family firms and R\&D behavior-New evidence from a large-scale survey. Res. Policy 2014, 43, 233-244. [CrossRef]

66. Wal, N.; Boone, C.; Gilsing, V.; Walrave, B. CEO research orientation, organizational context, and innovation in the pharmaceu-tical industry. RED Manag. 2020, 50, 239-254.

67. Lin, C.; Lin, P.; Song, F.; Li, C. Managerial incentives, CEO characteristics and corporate innovation in China's private sector. J. Comp. Econ. 2011, 39, 176-190. [CrossRef]

68. Bronwyn, H.; Hall, R.O. Does the market value R\&D investment by European firms? Evidence from a panel of manufacturing firms in France, Germany, and Italy. Int. J. Ind. Organ. 2005, 24, 971-993.

69. Yu, F.; Shi, Y.; Wang, T. R\&D investment and Chinese manufacturing SMEs' corporate social responsibility: The moderating role of regional innovative milieu. J. Clean. Prod. 2020, 258, 120840. [CrossRef]

70. Gilbert, C.G. Unbundling the Structure of Inertia: Resource Versus Routine Rigidity. Acad. Manag. J. 2005, 48, 741-763. [CrossRef]

71. Hafner-Burton, E.M.; Hughes, D.A.; Victor, D.G. The Cognitive Revolution and the Political Psychology of Elite Decision Making. Perspect. Politi- 2013, 11, 368-386. [CrossRef]

72. Nosić, A.; Weber, M. How Riskily Do I Invest? The Role of Risk Attitudes, Risk Perceptions, and Overconfidence. Oper. Res. Manag. Sci. 2012, 7, 282-301. [CrossRef]

73. Li, F.; Xu, X.; Li, Z.; Du, P.; Ye, J. Can low-carbon technological innovation truly improve enterprise performance? The case of Chinese manufacturing companies. J. Clean. Prod. 2021, 293, 125949. [CrossRef]

74. Driessen, P.H.; Hillebrand, B.; Kok, R.A.W.; Verhallen, T.M.M. Green New Product Development: The Pivotal Role of Product Greenness. IEEE Trans. Eng. Manag. 2013, 60, 315-326. [CrossRef]

75. Gelb, D.; Strawser, J. Corporate Social Responsibility and Financial Disclosures: An Alternative Explanation for Increased Dis closure. J. Bus. Ethics 2001, 33, 1-13. [CrossRef]

76. Shenkar, O. The Firm as a Total Institution: Reflections on the Chinese State Enterprise. Organ. Stud. 1996, 17, 885-907. [CrossRef]

77. Kang, L.S. Corporate Performance Vis-à-vis Executive Compensation-An Empirical Analysis of Selected Indian Compa-nies. Asia-Pac. J. Manag. Res. Innov. 2009, 5, 3-10.

78. Barberis, N.; Boycko, M.; Shleifer, A.; Tsukanova, N. How Does Privatization Work? Evid. Russ. Shops. 1995. [CrossRef]

79. Le, T.V.; O’Brien, J.P. Can Two Wrongs Make a Right? State Ownership and Debt in a Transition Economy. J. Manag. Stud. 2010, 47, 1297-1316. [CrossRef]

80. Bai, C.-E.; Xu, L.C. Incentives for CEOs with multitasks: Evidence from Chinese state-owned enterprises. J. Comp. Econ. 2005, 33, 517-539. [CrossRef]

81. Shao, D.; Zhao, S.K.; Wang, S.; Jiang, H. Impact of CEOs' Academic Work Experience on Firms' Innovation Output and Perfor-mance: Evidence from Chinese Listed Companies. Sustainability 2020, 12, 7442. [CrossRef]

82. Aguilera, R.; Duran, P.; Heugens, P.; Sauerwald, S.; Turturea, R.; VanEssen, M. State ownership, political ideology, and firm performance around the world. J. World Bus. 2020, 56, 101113. [CrossRef] 
83. Zhang, A.; Zhang, Y.; Zhao, R. A study of the R\&D efficiency and productivity of Chinese firms. J. Comp. Econ. 2003, 31, 444-464. [CrossRef]

84. Li, D.Y.; Huang, M.; Ren, S.G.; Chen, X.H.; Ning, L.T. Environmental Legitimacy, Green Innovation, and Corporate Carbon Dis-closure: Evidence from CDP China 100. J. Bus. Ethics 2018, 150, 1089-1104. [CrossRef]

85. Rong, Z.; Wu, X.; Boeing, P. The effect of institutional ownership on firm innovation: Evidence from Chinese listed firms. Res. Policy 2017, 46, 1533-1551. [CrossRef]

86. Bamber, L.S.; Jiang, J.; Wang, I.Y. What's My Style? The Influence of Top Managers on Voluntary Corporate Financial Disclosure. Account. Rev. 2010, 85, 1131-1162. [CrossRef]

87. Guo, Q.; Zhou, M.; Liu, N.; Wang, Y. Spatial Effects of Environmental Regulation and Green Credits on Green Technology In-novation under Low-Carbon Economy Background Conditions. Int. J. Environ. Res. Public Health 2019, 16, 3027. [CrossRef] [PubMed]

88. Cohen, J.; Cohen, P. Applied Multiple Regression/Correlation Analysis for the Behavioral Sciences; Lawrence Erlbaum Associates, Inc.: Hillsdale, NJ, USA, 1983.

89. Cui, R.; Wang, J.; Xue, Y.; Liang, H. Interorganizational learning, green knowledge integration capability and green innovation. Eur. J. Innov. Manag. 2020, 24, 1292-1314. [CrossRef]

90. Hillary, R. Small and Medium-Sized Enterprises and the Environment: Business Imperatives; Greenleaf Publishing: Sheffield, UK, 2000. 